\title{
Outstanding Farmer's Learning Style
}

\author{
ChenChia Hsu \\ National Chi Nan University \\ Department of Educational Policy and Administration \\ Nantou, Taiwan \\ aaachan2001@gmail.com
}

\begin{abstract}
The purpose of this study was to investigate the outstanding farmers learning styles. Based on the suggestions of research literatures, a structural questionnaire contains personal information, learning style questionnaire. The main study technique used was the questionnaire survey; this research is based on the farmers who were rewarded prize in public by Agriculture and Food Agency, Council of Agriculture, Executive Yuan from 2001 to 2010 . Totally 188 questionnaires were distributed, and 141 of them were received. After analyzing with statistical methods, the main findings are as follows:
\end{abstract}

1. Most outstanding farmers are "Accommodative" in the type of learning styles.

2. Different backgrounds are not linked to significant differences in outstanding farmers' personal background. learn.

Keywords-component; outstanding farmer, learning styles,

\section{INTRODUCTION}

In all of life's most important necessities of food, and daily life of farmers responsible for the production of food, but it is these farmers belong to the socioeconomically disadvantaged groups, how to make farmers out of poverty and the promotion of social upward mobility may, therefore, in-depth explore real farmers' learning style has its importance, particularly in the accession to the World Trade Organization(WTO) after Economic Cooperation Framework Agreement (ECFA) strait economic cooperation framework for farmers has brought unprecedented impact, but if we look at the crisis as farmers turn, constantly to adapt to the environment change, through the continuous learning in order to enhance their competitive advantage in the changing generations, the development of the knowledge economy infinite possibilities. This study aimed to understand the farmers' learning styles, learning styles because it knows who can make the teaching to reach educational goals, so that students achieving sustainable development and learning excellence, another farmer learning styles through research, research results available to farmers can make it could use more effective learning strategies, and farmers can provide relevant units intended to promote policy learning reference.

\section{LITERATURE REVIEW}

\section{A. Farmers in Low Socioeconomic Status and Relationship of Adult Learning}

According to Directorate-General of Budget, Accounting and Statistics, Executive Yuan, R.O.C.(Taiwan),(DGBAS) statistics show that in 2009 farmers in disadvantaged in the following will not help farmers to learn: 1. Employed population vulnerable: agriculture, forestry and fishery employment in total employment population ratio was $5.14 \%$, which is employed population vulnerable (DGBAS, 2009a). 2. Education for the disadvantaged: agriculture, forestry and fishery's degree in junior high or less was $74.56 \%$, forestry, fishery, animal husbandry is the overall education for the disadvantaged (DGBAS, 2009b). Education for the disadvantaged also affect future participation to continue learning, adult education generally considered as the most predictive of Education to participate in learning, that the higher the education level, the more likely to participate in learning, subsequent studies also support such Conclusion (Huang Fushun, 2002). 3. Vulnerable population age structure: agriculture 74 persons aged 45 or older accounted for $74.56 \%$, for the population age structure of the weak (DGBAS, 2009b). General studies have pointed out that the majority of young people involved in adult learning, mostly below the age of 45 years old adult (Huang Fushun, 2002). 4. Economic weakness: Every household annual disposable income of 753,776 dollars, than non-farmers annual disposable income 925,710 dollars, 171,934 dollars less (DGBAS, 2009c). Belanger and Valdivielso studies indicate that adult income level is higher, the higher the rate of participation in learning. Generally the higher the income, the more likely to participate in educational activities (Huang Fushun, 2002).

\section{B. The Meaning of Learning Styles}

Learning style (learning style) was also translated into learning styles (Yu-Chu Yeh et al, 2003). The word comes from the Greek style, mainly in the description of individual differences in human behavior, refers to the individual in many areas of activity preferred way of doing things or long habit patterns (Han Song, 2010).

Although scholars have proposed the definition and classification of learning styles are not the same, but the definition and classification of the scholars, we can say that there are numerous, and the classification used in the study of Kolb's classification, more in line with an outstanding farmer learning. Dewey saying "Education is the transformation of experience", which explains the learning experience is constantly restructuring or transformation process, the experience is learning the subject. Evans believes that experience learning in a variety of different contexts for, and convinced of the value of experiential learning, and sometimes overly formal institutions of high learning (Huang Fushun, 2002). Usually, farmers have experienced in life to all 
accidents, farmers in life to meet environmental requirements, are engaged in all activities All these farmers need the learners actively construct their own experiences. And Kolb's experiential learning, providing a benefit to farmers actively construct their own experience model, learners in the specific experience through observation and reflection, and then the formation of abstract concepts, actions to generate new experiences four stages of learning behavior, Kolb think but to learn from the experience of learning styles (experiential learning) developed by several message processing architecture. In practice, the issue of farmers were required to solve the problem through concrete experience, but the experience has not solve the problem, we must reflect on learning through the formation of new concepts to solve new problems, the formation of a learning cycle.

\section{Personal Background Variables on the Impact of Learning Styles}

Finishing learning styles research (Tsai Shu-Wei, 2003; Chen Ying Chi, 2005; Chen Village, 2004; Pei Qi, 2005; Huang Zi Ni, 2006), inductive influence learning styles sociodemographic variables are: gender, age, education level, years of learning style influence.

\section{Learning Style Scale}

In the second part of the questionnaire "learning style volume tables", including: Convergent, diffusion, assimilation model, Accommodative four types, each dimension are described as follows:

1. Convergent: pragmatist; adept theory for practical use, able to handle technology issues rather than social issues, with a "non-emotional character." Active learning preferences verification, abstract concepts.

2. Diffusion type: brainstorm aspects of the performance is good; like to observe others, will gather information, there is a wide range of cultural interests, innovative character. Learning preferences provincial thinking observation, concrete experience.

3. Assimilation type: thinker; adept at handling large amount of information grouped into theories of people are not interested in comparing, light weight logical practical value. Learning preferences provincial thinking observation, abstract concepts.

4. Accommodative: adventurer; easily adapt to the environment, like to use intuition rather than logic analysis, dependent on others for information rather than technical analysis, with action orientation. Active learning preferences verify specific experience.

\section{RESEARCH METHODS}

The study sample will be the Agriculture and Food Agency, Council of Agriculture of the selection of the farmers, and by the public award for the study. The sample source for Agriculture and Food Agency, Council of Agriculture of the selection of the farmers, and by the Agriculture and Food Agency, Council of Agriculture announced on the website of the top ten list of Shennong album to 2002-2010 winners of 214 people.

\section{A. Study sample}

TABLE I. LIST OF STUDY SAMPLE

\begin{tabular}{|c|c|c|c|c|c|c|c|}
\hline $\begin{array}{c}\text { year } \\
\text { award }\end{array}$ & 2002 & 2003 & 2004 & 2005 & 2006 & 2008 & 2010 \\
\hline $\begin{array}{c}\text { Outstanding } \\
\text { Farmer }\end{array}$ & 24 & 24 & 20 & 22 & 24 & & \\
\hline $\begin{array}{c}\text { Farm } \\
\text { women }\end{array}$ & 12 & 12 & 12 & 12 & 12 & & 10 \\
\hline $\begin{array}{c}\text { ten list of } \\
\text { Shennong }\end{array}$ & & & & & 10 & 10 \\
\hline $\begin{array}{c}\text { Model } \\
\text { farmers }\end{array}$ & \multicolumn{7}{|c|}{ Total:214 } \\
\hline \multicolumn{1}{|c|}{}
\end{tabular}

Source: researchers organize

\section{B. Analysis}

This study used questionnaires, this part of the questionnaire used Tsai Shu-Wei (2003) prepared by the "third edition Kolb Learning Style Inventory" (Learning Style Inventory, version 3,1999); After Chen Village (2004) rearranged become a "learning style Likert-type scale." And relend expert validity and pre-test to establish the reliability and validity, the results obtained by four learning styles scores: Convergent, diffusion type, accommodation type, assimilation model, the higher the score the tendency of their learning style type is more obvious. This study used Likert-type scale fivepoint scale way. Independent sample t-test (independent $\mathrm{T}$ test), single-factor analysis of variance (One-Way ANOVA)

\section{RESULTS AND DISCUSSION}

\section{A. Personal Background Characteristics}

The questionnaire total recovery of 149 valid questionnaires 141, according to the valid questionnaires statistical results, this section will be on the study sample personal background variables, including: gender, age, education, marital status, seniority and economic conditions, as shown in Table II. 
TABLE II. OF VALID QUESTIONNAIRES DISTRIBUTION OF PERSONAL BACKGROUND VARIABLES COMPILED CHART $(\mathrm{N}=141)$

\begin{tabular}{|c|c|c|c|}
\hline $\begin{array}{c}\text { Personal } \\
\text { background } \\
\text { category }\end{array}$ & group & $\begin{array}{c}\text { number } \\
\text { (N) }\end{array}$ & $\begin{array}{c}\text { Percentage } \\
(\%)\end{array}$ \\
\hline \multirow[t]{2}{*}{ Gender } & Male & 95 & 67.4 \\
\hline & Female & 46 & 32.6 \\
\hline \multirow[t]{3}{*}{ Age } & 50 yrs old below & 36 & 25.5 \\
\hline & 51 60 yrs old & 65 & 46.1 \\
\hline & 60 yrs old or more & 40 & 28.4 \\
\hline \multirow[t]{5}{*}{ Education } & Junior high school & 59 & 41.8 \\
\hline & $\begin{array}{c}\text { high school and } \\
\text { vocational education }\end{array}$ & 50 & 35.5 \\
\hline & Specialist & 19 & 13.5 \\
\hline & University & 6 & 4.3 \\
\hline & Institute or more & 7 & 5.0 \\
\hline \multirow[t]{4}{*}{ Marital status } & Married & 131 & 92.9 \\
\hline & Unmarried & 2 & 1.4 \\
\hline & Divorce & 1 & 0.7 \\
\hline & Widowed & 7 & 5.0 \\
\hline \multirow[t]{5}{*}{ Seniority } & 10 years below & 6 & 4.3 \\
\hline & 11 20 years & 24 & 17.0 \\
\hline & $21 \sim 30$ years & 49 & 34.8 \\
\hline & $31 \sim 40$ years & 37 & 26.2 \\
\hline & 41 years or more & 25 & 17.7 \\
\hline \multirow{8}{*}{$\begin{array}{l}\text { Personal annual } \\
\text { income status }\end{array}$} & 200 thousand below & 18 & 12.8 \\
\hline & $\begin{array}{c}200 \text { thousand } 300 \\
\text { thousand }\end{array}$ & 17 & 12.1 \\
\hline & $\begin{array}{l}300 \text { thousand } 400 \\
\text { thousand }\end{array}$ & 13 & 9.2 \\
\hline & $\begin{array}{l}400 \text { thousand } \sim 600 \\
\text { thousand }\end{array}$ & 6 & 4.3 \\
\hline & $\begin{array}{l}600 \text { thousand } ~ 800 \\
\text { thousand }\end{array}$ & 23 & 16.3 \\
\hline & $\begin{array}{c}800 \text { thousand } 1000 \\
\text { thousand }\end{array}$ & 21 & 14.9 \\
\hline & $\begin{array}{l}1000 \text { thousand } \sim 1500 \\
\text { thousand }\end{array}$ & 22 & 15.6 \\
\hline & 1.5 million or more & 21 & 14.9 \\
\hline
\end{tabular}

Source: researchers organize

\section{B. The Overall Analysis of Learning Styles}

From Table III that participated in the study distinguished among farmers, learning style patterns are "diffusion" of 34 of the largest number of people. Chi-square test of homogeneity results $\chi^{2}=7.11, \mathrm{p}=.07>.05$, which means that the study sample assigned to receive fit test.

TABLE III. OUTSTANDING FARMER LEARNING STYLE SITUATION ANALYSIS SUMMARY TABLE $(\mathrm{N}=141)$

\begin{tabular}{ccc}
\hline $\begin{array}{c}\text { Learning style } \\
\text { dimensions }\end{array}$ & Number & Percentage\% \\
\hline Diffusion type & 34 & 24.1 \\
Assimilative & 40 & 28.4 \\
Convergent & 23 & 16.3 \\
Accommodative & 44 & 31.2 \\
Total & 141 & 100.0 \\
\hline
\end{tabular}

Source: researchers organize

\section{Discussion}

Distinguished from Table 4-2 that learning style types of farmers the largest number is "Accommodative", outstanding farmers in the Kolb Learning Styles Inventory on the "Processing messages" on the dimension over the "active experiment" in "Accept information" preference bias on "concrete experience", this type of learning styles of learners in the learning process than the lack of "abstraction" and "reflection observation" relatively easy to adapt to the environment with the spirit of adventure, like to use intuitive analysis things; learning style type numbers were "assimilative" and "diffusion"; minimum of a "convergence type." This result (Huang Fushun, 2002; Chen Village, 2004; Chen Ying Chi, 2007; Huang Zhou, 2007) adult learners learning styles and study the relationship between learning outcomes are similar. According to the Council of Agriculture Committee Agriculture and Food Agency (2009) in the selection of the elements of outstanding farmers mainly committed to agricultural production and marketing of technological innovation, outstanding performance enterprise management, to promote the modernization of agriculture and industrial development with outstanding contributors. Seen from the above elements of the selection and marketing of technological innovation, enterprise management and the promotion of outstanding performance with outstanding contribution to the development of modern industry, the required marketing and sales capabilities and the ability to close, which also echoed by prominent farmers to adapt to the majority of findings.

\section{STUdies' SUGGestions}

\section{A. The prominent farmers learners advice: understand} their own learning styles

1) Recommends farmers through the "learning style" assessment tool to understand their unique learning styles, to understand their own learning strengths, you can follow their own learning interests and needs, choose the learning process is more suitable for their own learning, it can make learning additive effects play a multiplier effect..

\section{B. The farmer education authorities recommend:} arrange appropriate teaching patterns, teaching styles and learning styles

The study found that outstanding farmers to adapt learning style model for the majority, the order of the assimilation model, diffusion and convergence type, various educational institutions in arranging learning content, learning styles should arrange with the relevant knowledge about teaching, and teachers in teaching the process should seek teaching styles and learning styles with, in order to effectively help farmers learn and improve learning. For example: a traditional lecture courses, plus pictures (images and display, etc.) to discuss the curriculum, participate in activities for farmers to choose courses and other courses.

\section{ACKNOWLEDGMENT}

Thank Shu-Jyuan Wu for your knowledge and expertise, and for taking on the challenge of teaching special children with grace, humor, and enthusiasm. You make a difference. 


\section{REFERENCES}

[1] DGBAS, "EMPLOYED PERSONS BY INDUSTRY." No date, from: ttp :/ / www.dgbas.go v.tw/public/data/dgbas04/bc4/year/97/table12.xls, 2009a.

[2] DGBAS, "employed by the vocational education and age." No date, from: ttp :/ / www.dgbas.go v.tw/public/data/dgbas04/bc4/year/97/table45.xls, 2009b.

[3] DGBAS. "The average household farm and non-farm household and per capita disposable income." No date, from: http://win.dgbas.gov.tw/fies/doc/result/97/a11/Year13.doc, 2009c.

[4] Agriculture and Food Agency, Council of Agriculture. "2009 Top Ten selection and recognition of Shennong plan." No date. Retrieved from: http://www.afa.gov.tw/tenclassic_index.asp?CatID=116, 2009.

[5] Pei Qi, project manager of the personality traits, learning styles and study the relationship between conflict handling. Wen Tong University, international trade master's thesis, unpublished, Hsinchu, 2005.

[6] Chen Ying Chi, Industrial Design study of student learning styles. Yunlin University industrial design master's thesis, unpublished, Yunlin County, 2005.
[7] Chen Village, adult learners learning style network, self-regulation and the relationship between learning outcomes research. Kaohsiung Normal adult education master's thesis, unpublished, Kaohsiung, 2004.

[8] Huang $\mathrm{Zi} \mathrm{Ni}$, middle-aged and older people learning styles Comparative Study - Case Study of Taipei City Community College. Chung Cheng University Adult and continuing education master's thesis. Unpublished. Chiayi County, 2005.

[9] Wong Chau, Yunlin County Community College adult learners learning styles and learning relationship studies. National Chung Cheng University Institute of Adult and Continuing Education Master's thesis, unpublished, Chiayi County, 2007.

[10] Huang Fushun, adult learning. New York: Routledge, 2002.

[11] Yu-Chu Yeh, high source today, Xiu Hui-lan, Chen Shifen, Zeng Huimin, Angelina, Chen Huiping, educational psychology. New York: Psychology Press, 2003.

[12] Tsai Shu-Wei, high school students learning styles, self-regulated learning and academic achievement relationship. Changhua University of guidance and counseling master's thesis, unpublished, Changhua City, 2003.

[13] Han Song, distance education learning style on learning performance impact evaluation. Journal of Distance Education, 28 (2),106-110, 2010. 